\title{
ECONOMIC IMPACTS ON DESTINATION AIR TRAFFIC FOLLOWING A FLAG CARRIER'S MARKET EXIT: A CASE STUDY FOR BUDAPEST
}

\author{
Adam Torok ${ }^{1}$, Florian Heinitz ${ }^{2}$ \\ ${ }^{1}$ Division of Transport Policy and Economics, Institute for Transport Sciences, \\ Than Karoly 3-5, 1111 Budapest, Hungary \\ ${ }^{2}$ Institut Verkehr und Raum, Erfurt University of Applied Sciences, \\ Altonaer Strasse 25, 99085 Erfurt, Germany \\ E-mails: ${ }^{1}$ torok.adam@kti.hu (corresponding author); ${ }^{2}$ Heinitz@fh-erfurt.de
}

Received 30 September 2013; accepted 20 November 2013

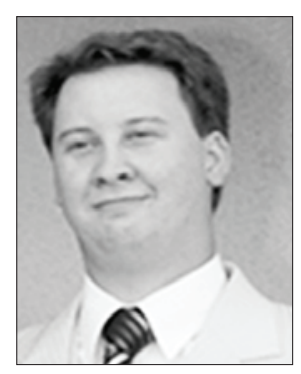

Adam TOROK, $D r$

Date of birth: 18 January 1981.

Education: Brno University of Technology (BUTE), Transportation Faculty, MSc in Transport Engineering (2004); MSc in Transport Management (2007); PhD in Transport Science (2008). Affiliations and functions: 2004-2008 - participation in Developing Harmonised European Approaches for Transport Costing and Project Assessment (HEATCO), EU 6th Framework Programme, Research and Development Project. 2005 - design of a database for the National Transportation Authority. Database of technical and environmental vehicle inspectors. 2004-2005 - participation in the project 'The contradiction of liability of maintenance and feasibility at Public Transport of Budapest Plc', done by BUTE Department of Transport Economics. 2005-2006 - participation in the project co-financed by International Road Transport Union (IRU) and Organisation for Economic Co-operation and Development (OECD) Attacks on international drivers of heavy goods vehicles'. 2006 - leader of the economic workgroup for Advanced Vehicles \& Vehicle Control Knowledge Centre in the project 'Feasibility studies of fleet management at Hungarian Post Plc'. 2006-2007 - Thessaloniki for Hellenic Institute of Transportation. Development of a port choice model for common logistics operation in the region of Crete. 20072008 - part-time job at KTI - Institute for Transport Science Non-Profit Ltd. 2008 - member of PIARC Technical Committee A.3. 2008 -full-time job at KTI - Institute for Transport Science NonProfit Ltd. 2009 - part-time job at BUTE - Department of Transport Economics. Research interests: mathematical decision modelling, environmental pollution, climate change. Publications: author of 57 articles (21 in a foreign language), 1 lecture notes, 21 research studies, 47 presentations (21 in a foreign language).

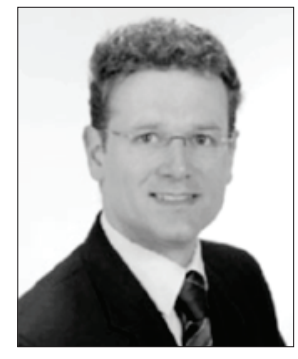

Florian HEINITZ, Prof. Dr

Year of birth 1972.

Education: degrees in Physics and Economics, Universities of Stuttgart, Marburg, and Karlsruhe. Memberships: Air Transport Research Society (ATRS), World Conference on Transportation Research Society (WCTRS), Transportation Research Board, TransBaltica Conference, Vilnius Scientific Committee (2009). German Aviation Research Society (G.A.R.S.), Scientific Board Periodica Polytechnica, Ser. Transportation Engineering, Budapest.

Research interests: decision support systems in the transport industry, travel demand modelling/ customer analytics, air transport economics.

Academic honours and grants: 1996 - Heraeus Foundation Prize for outstanding graduates in physics. 1997 - Transportation Research Scholarship of the Krupp Foundation. 2002 - Etienne Laspeyres Prize in National Economics and Statistics.

Publications: author and co-author of 21 articles.

Present position: Head of Transport and Spatial Planning Institute, Coordinator of Studies, MSc Programme 'Intelligent Transport Systems and Mobility Management' (IVM). Sino-German University of Applied Sciences (CDHAW), BEng Programme 'Economic Engineering': Departmental Coordinator at FH Erfurt. 
Abstract. After 66 years of existence, the Hungarian state carrier MALEV had to cease operations in 2012 because of its financial situation. The sudden market exit affected more than half of the traffic at Budapest's Liszt Ferenc Airport (BUD). This paper aims to investigate the market reactions, taking particular note of the role of low-cost carriers (LCC). The examination of a legacy carrier's situation contending with dynamic low-cost airlines establishes the basis for the case of Budapest. Originating with the hypothesis that the shift from a flag carrier to an LCC dominated market has effects on incoming tourism, this paper also studies the secondary effects of this situation.

Keywords: post-liberalised airline market, flag carrier, low-cost carrier, market exit, incoming tourism.

\section{Introduction}

After 66 years of existence, the Hungarian state carrier MALEV had to cease operations in 2012 because of its financial situation. The sudden market exit of one of the oldest airlines worldwide affected more than half of the traffic at Budapest's Liszt Ferenc Airport (BUD). Soon after, low-cost carriers not only took over the vacant market shares but also restructured the passenger market. This article summarises a case study conducted for BUD. The paper is organised as follows. Section 2 recounts the transitions in the airline market structure, putting emphasis on strategic alliances as a strategy to withstand competition. Section 3 analyses the struggle of flag carriers, a specific developments in Europe. The empirical results for BUD are compiled in section 4, taking note of the post-exit situation of incoming tourism. The preceding information is the basis for further analysis and discussion in the concluding section 5 .

\section{Transitions of the airline market structures}

Aviation was traditionally a strictly regulated industry, dominated by national flag carriers and state-owned airports. The global deregulation and liberalisation of air transport, which began in the USA at the end of the 1970 s, triggered a path of development. The numerous changes include the introduction of hub and spoke networks and the evolution of price-competition and low-cost business models, resulting in the rise in load factors, but also a scarcity of airports (Mirosavljević et al. 2011).

Governments liberalised controls over route entry, capacity and pricing and began to relax restrictions on foreign ownership. At the same time, airlines were seeking to break free from the constraints that the bilateral system of air service agreements imposed upon their networks and upon the markets they could serve. The experience of deregulation in the USA (and elsewhere) demonstrated the critical importance of large airline size and the economies of scale that go with it, especially in the field of marketing. Consequently, the long-term outcome of deregulation is increased market concentration, such as can be observed in the US domestic market. Airlines expected that the liberalisation of international routes would have much the same effect, and to achieve the benefits of large size, airlines teamed up with each other, forming various kinds of strategic alliances. In one of the most comprehensive surveys, air- line executives stated that they felt a growing sense of urgency to get their consortia together before the best partners were taken. Most partnerships tended to be between just one airline and another, but the emergence of several major groupings, or 'galaxies', became rather noticeable. Airlines may cooperate below the threshold of a merger in various ways: through equity stakes, code sharing, technical assistance, or marketing agreements. To some extent, the proliferation of code sharing and other marketing agreements was a partial substitute for multilateral collaboration through IATA. What fundamentally accounts for the proliferation of alliances, both generally in business and in airlines in particular? This is an interesting question in its own right. It is also central to the formulation of business strategy. It happened because the potential for sustainable advantage to be achieved through inter-firm collaboration depended on the nature and strength of the underlying forces that serve as motivation for alliances. The actual contract design can vary from industry to industry and from case to case. However, it is widely expected that the growing number of alliances, possibly followed by some outright mergers, will accelerate the concentration processes in the airline industry. As stated earlier, the forecasts of how many airlines will survive and of how far the industry will be dominated by some very large carriers can vary (Burton, Hanlon 1994).

\section{Flag carriers versus LCC in Europe}

Observers of the European airline industry have long believed that the flag carrier system, though affirming national pride, has created too many airlines and led to inefficient excess capacity. The suggested remedy is consolidation of the European industry via cross-border mergers, an avenue that is now open as a result of EU deregulation. The first major consolidation event was the merger of Air France and KLM. Most major international carriers belong to one of the global alliances (Brueckner, Pels 2005).

Increased traffic and revenues can be generated by the merged airlines through the better alignment of schedules, routes, and well-coordinated product and pricing strategies (Tseytlina et al. 2013). Seamless connections can be offered and market share gained from competitors. As a result of increasing market power, fares (yields) and revenues might also be increased in certain markets where the two airlines had previously 
been competing (hence network overlap of the merging airlines is important). However, competition authorities might attach conditions to a merger that reduces the likelihood of these benefits being realised. It should be added that a sizeable proportion of this category of merger benefits might be achieved through an immunised strategic alliance. The merger between British Airways (BA) and Iberia is an example of this: most of its reported merger benefits were on the cost side, since the revenues will already have been boosted by the granting of antitrust immunity to the alliance between BA, Iberia and American Airlines (Merkert, Morreli 2012).

In the airline industry, a distinction is often made between an 'FSNC model' (full-service network carrier) and an 'LCC model' (low-cost carrier) (Tretheway 2004). LCCs and FSNCs are frequently seen to embody distinct spatial models (i.e. LCCs are often claimed to be characterised by point-to-point network structures, whilst FSCs operate spatially concentrated networks organised around hubs). These world cities have become hubs in the global networks of air transportation (Smith, Timberlake 1998). On the other hand, globalisation and space adjusting technologies have resulted in a global convergence of time-space (Stankūnas, Kondroška 2012). This means that peripheral areas have converged at a more rapid rate in time-space than core areas have (Janelle 2004). This increasing integration into global networks has allowed airlines to establish direct linkages between non-hub cities, leading many commentators to suggest that the old 'hub-and-spoke' network system characterised by spatially concentrated networks is becoming less relevant (O’Connor 2003). Such changes, and the liberalisation of the airline industry more generally, have resulted in a number of mixed and powerful effects (Doganis 2001; Pickrell 2004). Many well established and formerly stated-owned airlines in North America, Asia, and Europe are not financially stable in the liberalised systems in which they now, for the most part, operate (Vowles 2000; Nolan et al. 2004). Liberalisation on all three continents has, for a number of reasons, allowed LCCs to gain significant market shares (Jarach 2004). The growth of these carriers has been surprising; they carry 20\% of all European passengers (Sparaco 2004). The success of LCCs cannot be described better than stating that Ryanair is one of the most profitable airlines in the world (Graham 2009).

Since the 1980s, two important aviation trends have dominated air transport research: airline market consolidation and the growth of low-cost carriers. However, very little research has considered the merger and acquisition activity of low-cost airlines (Bilotkach et al. 2012). The liberalisation of the intra-EU air services market provided the legislative framework in which low-cost carriers (LCCs) could develop. The 'Third Package' of aviation measures came into force in January 1993, with full cabotage following in 1997. This market liberalisation allowed airlines to operate between any points in the European Union (EU). These new regulations have had a similar effect to the deregulation of the US domestic market around twenty years earlier. US deregulation saw the establishment and growth of Southwest Airlines, the archetypal low-cost carrier. Ryanair was the first EU airline to take advantage of the new European regulatory environment. The company based its strategy on the successful Southwest model, which quickly proved to work perfectly well in Europe. Soon after, start-ups like easyJet and Debonair also launched low-cost services. Many legacy carriers reacted to the threat of low-fare airlines by establishing their own LCC subsidiaries (including BA's Go and KLM's Buzz), yet most did not succeed (Francis et al. 2006). After a few years, the market went through an initial wave of consolidation. Market leaders Ryanair and easyJet both acquired smaller competitors, Buzz and Go respectively, whilst many other small carriers collapsed (Danklefsen 2007). By 2011, one hundred and ten low-cost carriers had entered the EU market but only thirty-two survived (Mason et al. 2013). The rest went out of business, were acquired, or merged with a competitor. (Lenartowicz et al. 2013). According to the European Cockpit Association (European ... 2002), in 2000 the European LCCs transported 20.7 million people $(8.6 \%$ of the market), and these figures have continued to strongly increase since then. The two main airlines, Ryanair and easyJet, have indeed reached a European scope, exceeding that of small- or medium-sized full-service network carriers (FSNC): in 2004 they transported 26.4 and 24.3 millions passengers respectively. Furthermore, Ryanair and easyJet ordered 125 and 120 new aeroplanes in 2002 with another option of 125 and 120 for 2003. This gives an idea of their ambitions (considering, of course, that some of those planes are intended to replace older ones). Many academic papers have recently been published on LCCs (Dobruszkes 2006). M. Franke (2004) and M. Tretheway (2004) discuss the competition between traditional airlines and LCCs, and so does W. Morrison (2004), who also looks into the role of the authorities controlling the competition. D. Gillen and A. Lall (2004), G. Francis et al. (2003) and S. Barrett (2004a) analyse the relations between LCCs and airports, while G. Williams (2001) deals with competition between charter carriers and 'no-frills' airlines.

The internal market has eliminated all commercial restrictions for airlines flying within the European Union. Constraints on routes, number of flights, tariff policies, etc. have been removed. EU airlines are permitted to provide air services on any route within 
the EU. As a result, prices have fallen dramatically, especially on the most popular routes (Mueller et al. 2012). European aviation now operates with over 130 scheduled airlines, a network of over 450 airports, and 60 air navigation service providers. The aviation sector employs more than 3 million people in the European Union. Airlines and airports contribute more than 120 billion EUR to the European gross domestic product. According to European figures, the airports in Europe have spent 7.5 billion EUR annually on capital expenditures over the past five years. As for the future, there are plans to spend 8.1 billion EUR annually between 2006 and 2010 and 8.5 billion EUR annually between 2011 and 2015 , resulting an $8 \%$ and $13 \%$ increase respectively (Kővári, Török 2010).

Transportation, and within this air transport, has a positive effect on national economic processes, consumption and the circle of consumers is increasing, mobility is growing, and overall, due to this, the standard of living is increasing. Investments in the infrastructure of air transport may appear as a positive effect, since new businesses will operate and the value of the real estate that can be found there may grow. Air transport has countless industrial and commercial relations and in this way contributes to GDP. Air transport also reduces travel time significantly (Legeza 2001).

Contemporary transport analyses are based on safety and economic equilibrium. The air transport sector recognises the $2 \mathrm{P}$ dilemma as the crucial decision-making tool. This means that all interested parties in aviation are balancing between productivity and profitability limits (Cavka, Cokorilo 2012).

But perhaps the most important economies of scope come from the greater ability of large airlines to configure networks in hub-and-spoke patterns and through this secure some gains in route traffic density. It is well known that the economies of route traffic density can be quite significant (Bailey et al. 1985). These economies arise when greater density enables the airline to use larger, more efficient aircraft with lower costs per seat-mile and/or to operate at higher service frequencies and consequently at higher seat-load factors, leading to lower costs per passenger mile. An increase in density may also permit more intensive utilisation of aircraft and crews, operating more flights per day (Legeza et al. 2010). For all these reasons, average costs fall as traffic density increases, and hubbing has a major effect in increasing density. Hubbing increases density by enabling the airline to consolidate traffic from many different origin-destination markets onto a much smaller number of links in the network. It makes it possible for the airline to carry, on a single spoke, passengers with different origins but the same destination (or passengers with different destinations but the same origin). In this way, hubbing reduces the number of round trips necessary to transport a given number of passengers over a given set of itineraries. Total passenger miles may or may not increase, depending on the extent of which passengers fly 'dog legs', but the main effects in reducing average cost come from a reduction in sectors flown, an increase in aircraft size and/or a rise in service frequency, and the load factor. Alliances encourage interline hubbing by facilitating cooperation between domestic and international services where restrictions on cabotage prevent the international carrier from serving domestic routes and where, under existing bilateral air service agreements, the domestic carrier has no traffic rights on the relevant international routes (e.g. BA/USAir at Pittsburgh, British Midland/ SAS at London Heathrow, Lufthansa/Lauds Air in Vienna). They also encourage closer links between the services of two international carriers (e.g. Northwest/ KLM, Lufthansa/United, Iberia/Aerolineas Argentinas). It is possible through forming alliances to make good fits between the networks of the partners and to provide swift connections at the hub airports that are served by each partner. This, of course, was a main objective behind the establishment of the global Excellence Network formed by Delta, Swissair and SIA (Burton, Hanlon 1994).

Within Europe, there has been significant growth in the number of low-cost carriers (LCCs) operating. One feature of the low-cost model is the use of secondary or regional airports. These airports compete with each other to secure the services of LCCs, a situation exploited by the airlines to reduce their costs as much as possible. Given airport charges can represent around $12 \%$ of LCCs' costs (Doganis 2001), this focus is understandable. The airport choice, however, reflects more than just the cost factor. It is therefore important for airport management to understand the relative importance of these factors to offer the service required by the airline (Warnock, Andrew 2005).

Our hypothesis is that the carrier market (supply side) has influence on touristic demand (demand side).

\section{Case study for Budapest airport}

The authors have investigated the situation just before and after the bankruptcy of the national flag carrier in Hungary. On 1 February 2012, the Hungarian national carrier MALEV ceased operating its intra-European network. The European destinations in 2011 are depicted in figure 1.

Due to the market exit, the capacity and maintenance needs of a fleet of six Boeing 737-600, seven Boeing 737-700, five Boeing 737-800, four Bombardier Dash 8 Q400 became obsolete. BUD lost about one-quarter of its flights (Fig. 2). 


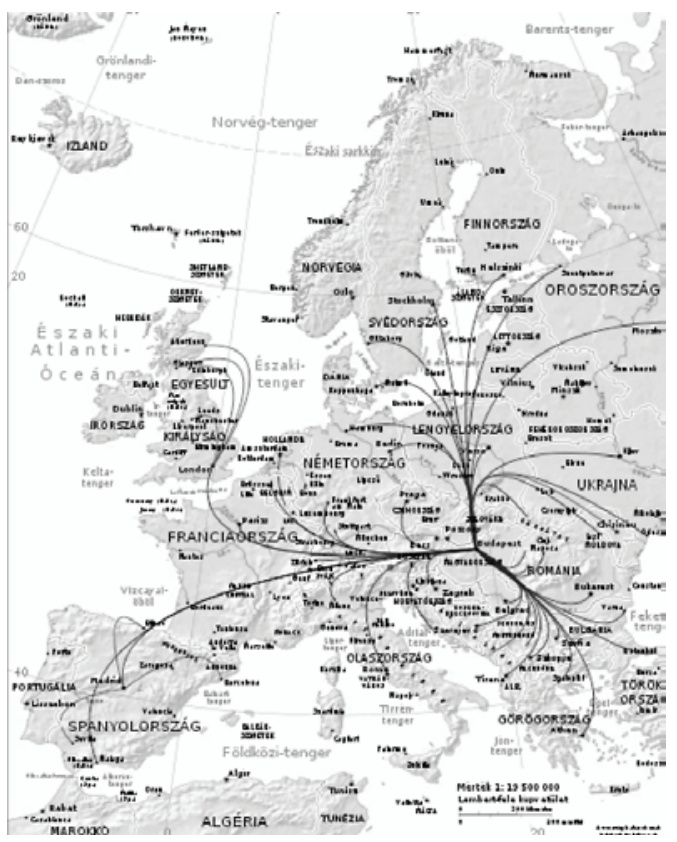

Fig. 1. European destinations of MALEV (Source: MALEV)

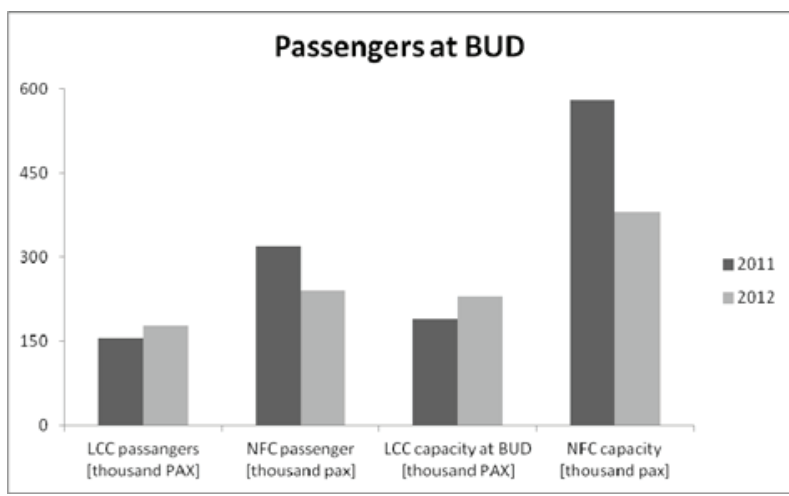

Fig. 2. Passengers at Liszt Ferenc Airport (BUD) (Source: own edition based on Hungaro Control Data)

Transit flow will not be analysed, because the bankruptcy of MALEV has no effect on it. Only the effect of the economic crisis can be observed, and the forecasted increasing tendency has been halted (Fig. 3).

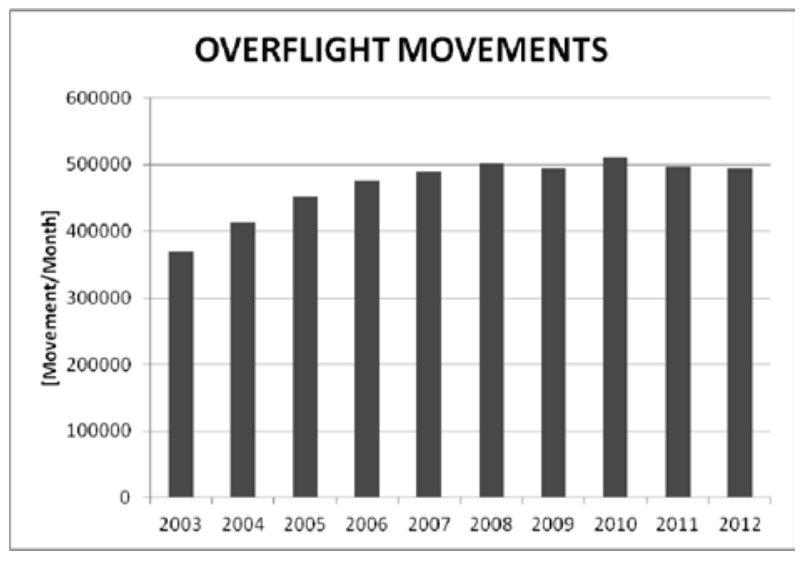

Fig. 3. Yearly overflight movements (Source: own edition based on Hungaro Control Data)
There has been significant change in arrivals and departures beginning in 2012 due to the bankruptcy of national flag carrier MALEV. One can see a significant decrease in February of every year investigated (Fig. 4).

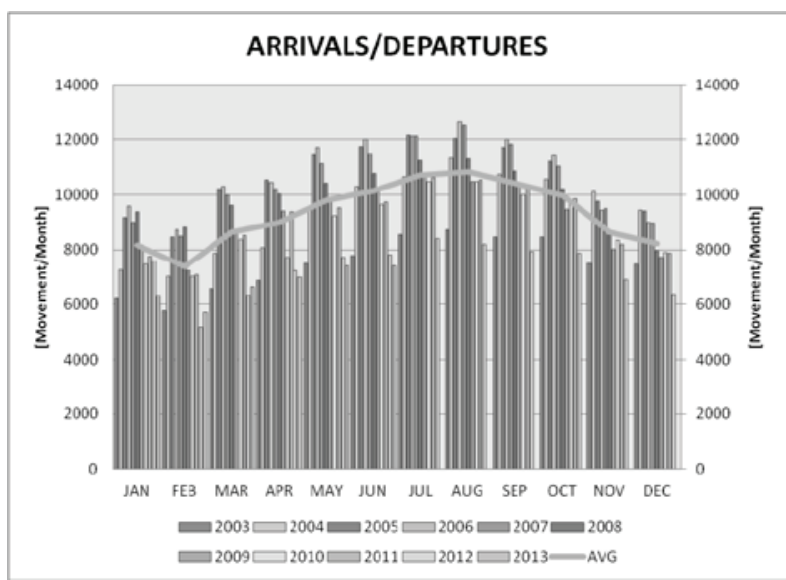

Fig. 4. Arrivals and departures (Source: own edition based on Hungaro Control Data)

Further investigation is necessary based not only on movements but also on the number of passengers. As can be seen (Fig. 5), the number of passengers has not decreased significantly following the collapse of MALEV.

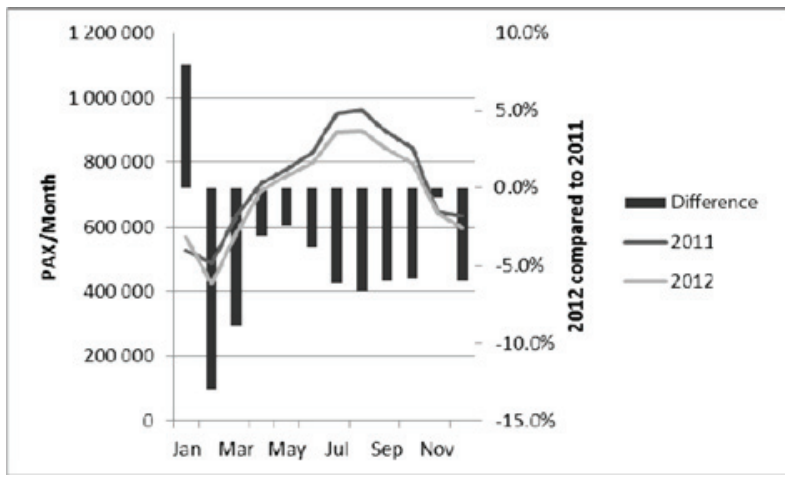

Fig. 5. Demand changes 2012 vs. 2011 at BUD (Source: own edition based on Hungaro Control Data)

Low-cost carriers that are working with higher occupancy (Fig. 6) filled the market space immediately.

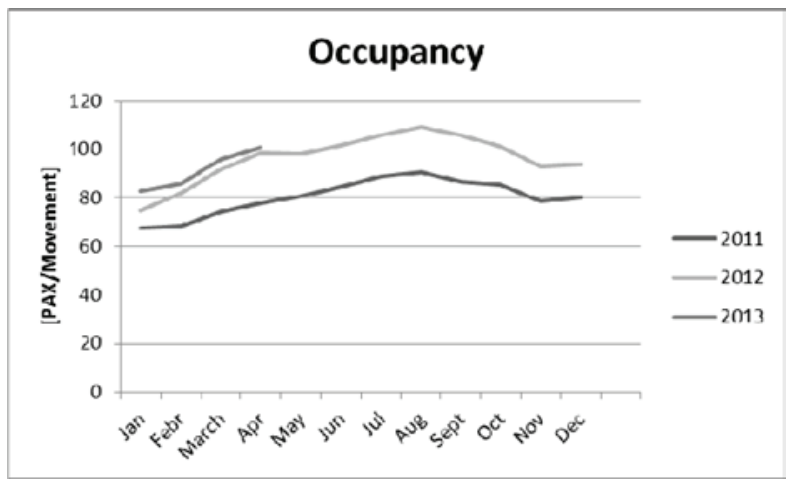

Fig. 6. Average occupancy (Source: own edition based on Hungaro Control Data) 
To understand the situation better, the market shares based on number of passengers need to be investigated. As can be seen (Fig. 7), MALEV was continuously losing its market share before it went bankrupt.

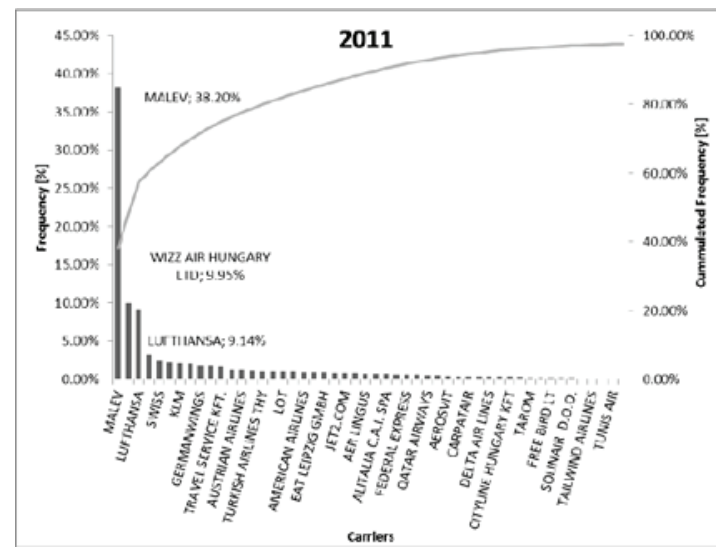

Fig. 7. Market share of carriers at Liszt Ferenc Airport (BUD) (Source: own edition based on Hungaro Control Data)

After having seen that the LCCs have significantly raised their market share at Liszt Ferenc Airport (BUD), the authors investigated the LCC-related planes and passengers (Fig. 8).

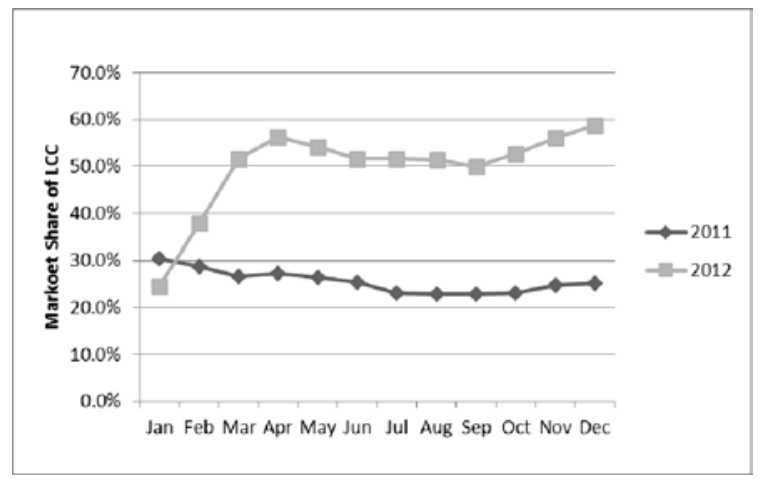

Fig. 8. Market share of LCCs by passengers (Source: own edition based on Hungaro Control Data)

As the leading LCC in the Hungarian market, WizzAir has benefitted the most from the bankruptcy of MALEV. New destinations have been established (Fig. 9).

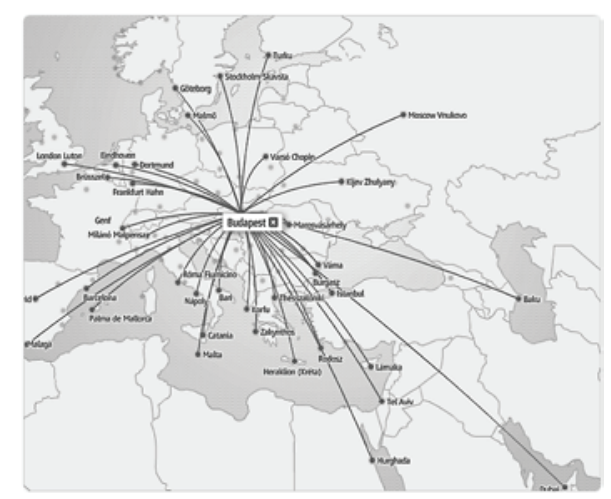

Fig. 9. Route network of WizzAir (Source: WizzAir)
There is a large amount of literature that analyses and justifies the role that airports and air traffic play in the economic activity of towns and cities in their surroundings (Brueckner 2003; Button et al. 1999; Green 2007). Thus, airports are recognised as being dynamic motors of social and economic development in these regions (Echevarne 2008), supporting local economic activity and driving new investments in their areas while at the same time helping to attract the headquarters of large firms to their corresponding urban areas (Bel, Fageda 2008). For J. A. W. Robertson (1995), airports could turn into the largest single employer in a region, which would favour administrative and auxiliary employment (Debbage 1999; Debbage, Delk 2001), high-technology jobs (Button et al. 1999), or possibly create job opportunities for less skilled workers or for local unemployed people (Robertson 1995). J. K. Brueckner (2003) goes further still and quantifies a $10 \%$ increase on tourism in a metropolitan area as leading to an approximate $1 \%$ increase in employment in service-related industries. In general terms, the emergence of LCCs has contributed to an increase in the tourist and leisure market at many destinations. It has created business opportunities while at the same time it has stirred up heated debate in the tourist sector in the surroundings of many regional airports. Conclusions drawn from this debate in each of these environments usually influence local and regional governments' policies for promoting tourism, including possible subsidies or aid for the introduction of LCCs. For this reason, when they make their decisions, these governments need to be aware of the view held by the sector itself of the ever more costly demands of the LCCs. There is, however, a lack of work analysing the effects that the introduction of LCCs at underutilised regional airports is having on economic agents and their behavioural responses (Castillo-Manzano et al. 2009). In this respect, and unlike earlier papers that search for correlations between time series, the aim of this paper is to take an in-depth look at the view that is held of the LCC phenomenon and the effects that LCCs have on the various tourism segments of the tourist sector in the towns and cities in the surroundings of the aforementioned regional airports.

As can be seen in figure 10, the share of 1-day trips is nearly constant, the share of 1-3-night stays has decreased, and the share of 4-or-more-night stays has increased. 


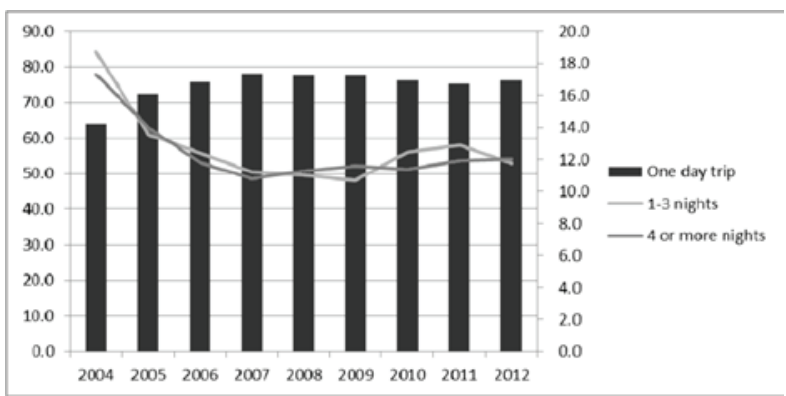

Fig. 10. Share of tourists by how long they stayed in Budapest (Data Source: WizzAir, 2013)

\section{Further analysis and discussion}

According to a report of Budapest Airport in 2012, 8.5 million passengers were served, while in 2011 the total was about 8.9 million passengers. In 2011 MALEV brought 1.5 million transit passengers to Budapest. Compared to Vienna or Bratislava, Budapest has behaved as a minihub, although Budapest had the opportunity to grow more to be a Central European hub (Fig. 9)

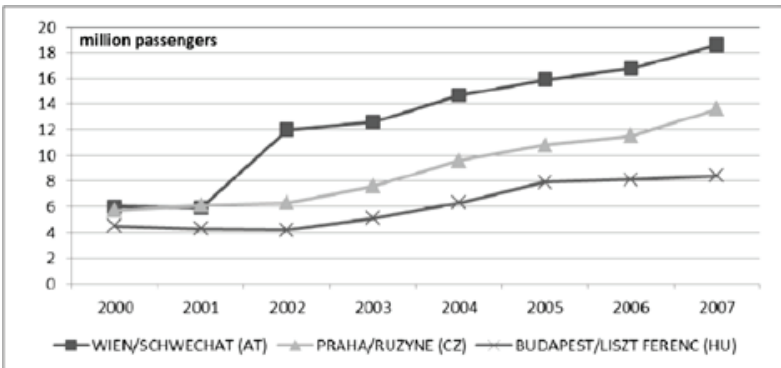

Fig. 11. Different development paths in the Central European region (Source: own edition based on Hungaro Control Data)

If in January 2012 only 100,000 transit passengers are considered, then one can easily calculate that in 2011 there were 7.4 million passengers and in 2012 there were 8.4 million passengers who stayed in Budapest. Thus it can be concluded that the bankruptcy of MALEV gave rise to a million tourists arriving in Budapest. According to a report of the Hungarian Statistical Office (2013), the number of foreign guests in Hungarian hotels increased by $8.5 \%$ in 2012 . The number of foreign-guest nights has also increased significantly, $14 \%$ in 2012 . This increase can be assigned to the MALEV bankruptcy and the benefits can only be connected to Budapest.

Airline business models are not a static phenomenon; rather, they repeatedly undergo changes in response to the basic problem of route density in air transport; i.e. how many people you can book on an airplane at the same time, to the same destination, at a combination of fares that will ultimately cover the total cost of operating the flight. Full-service carriers for example use the hub and spoke system to create 'factories to manufacture route density' (Levine 2009). In the context of the route density problem, a particular hub's viability can only be defined within upper and lower boundaries. At the lower boundary, the hub O\&D market's minimum size and prosperity is required to guarantee the relatively high yield from direct air services at the hub as compensation for the lower yield from the indirect air services provided to transfer passengers. At the upper boundary, hubbing comes with a growing average cost if the intensity of the connection waves starts to increase. The hub's upper limits are clearly illustrated by the operational complexity and vulnerability of a megahub in terms of costly baggage handling systems, long aircraft turnaround times, rapid increases in costly no-connection rates in bad weather conditions, high airline labour costs at the hub, and additional peak capacity costs. Lowcost carriers emerged following deregulation of the US domestic market and liberalisation of the European market. First in the United States, later in Europe, and then finally all over the world, LCCs eliminated these hubbing costs by serving a point-to-point system, often operated from secondary airports at low fares. The increasing use of low-cost carrier services reflects customer preferences for low fares and point-to-point travel and a dislike of the congestion, confusion, and long walking and waiting times at hub airports. S. Barrett (2004b) states that the full-service carriers themselves have accommodated the rise of the LCCs by concentrating their operations on hub airports, which enabled LCCs to bypass the hubs and avoid constraining connections. Regarding the rapid growth of the low-cost airline business model, it can be observed that LCCs have been able to cope with route density problems by generating new demand, as well as by attracting passengers from other transport modes and from full-service carriers by offering lower fares. Actually, the low fares resulting from the cost structure of LCCs (Dennis 2007) have enabled them to provide scheduled services to many more low density routes than one could ever expect from FSCs. Yet owing to the tremendous growth of LCC networks, an end to this network expansion may become visible, even if costs are rigorously kept down. LCCs are seemingly once again confronted by increasing route density problems (Levine 2009). LCCs are attempting to solve this problem by using specific airport categories, adjusting route frequency, selecting city pair markets with less price sensitive demand, and generating ancillary revenues (Dobruszkes 2006).

Route density in European O\&D markets will ultimately limit the growth prospects for LCCs in Europe. The growth figures for Europe's LCC sector are nevertheless impressive. CAPA (2010a, b) for example reports that LCCs occupy a $36 \%$ share of total seat capacity within the European Union. Route density constraints will likely lead to a slowdown in organic LCC growth over the next few years, forcing LCCs to (partly) adopt 
other business strategies for future growth. Examples of new business strategies to assure future growth include: shifting to primary airports, starting hubbing activities that enable passengers to transfer from one flight to another, signing codeshare agreements, entering alliances, and acquiring other airlines.

\section{Acknowledgement}

This work is connected to the scientific programme of the 'Development of quality oriented and harmonized $\mathrm{R}+\mathrm{D}+\mathrm{I}$ strategy and functional model at BME' project. These projects are supported by the New Szechenyi Development Plan (Project ID: TÁMOP-4.2.1/B-09/1/ KMR-2010-0002). The authors are grateful for the support of the Bólyai János Research Fellowship of HAS (Hungarian Academy of Sciences).

\section{References}

Bailey, E.; Graham, D. R.; Kaplan, D. P. 1985. Deregulating the Airlines. Cambridge, MA: MIT Press.

Barrett, S. 2004a. How do the demands for airport services differ between full-service carriers and low-cost carriers?, Journal of Air Transport Management 10(1): 33-39. http://dx.doi.org/10.1016/j.jairtraman.2003.10.006

Barrett, S. 2004b. The sustainability of the Ryanair model, International Journal of Transport Management 2(2): 89-98. http://dx.doi.org/10.1016/j.ijtm.2004.12.001

Bel, G.; Fageda, X. 2008. Getting there fast: globalization, intercontinental flights and location of headquarters, Journal of Economic Geography 8(4): 471-495. http://dx.doi.org/10.1093/jeg/lbn017

Bilotkach, V.; Clougherty, J.; Mueller, J., et al. 2012. Regulation, privatization, and airport charges: panel data evidence from European airports, Journal of Regulatory Economics 42(1): 73-94. http://dx.doi.org/10.1007/s11149-011-9172-1

Brueckner, J. K.; Pels, E. 2005. European airline mergers, alliance consolidation, and consumer welfare, Journal of Air Transport Management 11(1): 27-41.

http://dx.doi.org/10.1016/j.jairtraman.2004.11.008

Brueckner, J. K. 2003. Airline traffic and urban economic development, Urban Studies 40(8): 1455-1469. http://dx.doi.org/10.1080/0042098032000094388

Burton, J.; Hanlon, P. 1994. Airline alliances: cooperating to compete?, Journal of Air Transport Management 1(4): 209227. http://dx.doi.org/10.1016/0969-6997(94)90013-2

Button, K. 1991. Airline Deregulation: International Experiences. New York: New York University Press.

Button, K.; Lall, S.; Stough, R., et al. 1999. High-technology employment and hub airports, Journal of Air Transport Management 5(1): 53-59.

http://dx.doi.org/10.1016/S0969-6997(98)00038-6

CAPA: Centre for Asian Pacific Aviation. 2010a. Ancillary Revenues to Total USD 23 billion in 2010 and Set to Triple [online], [cited 20 September 2013]. Available from Internet: www.centreforaviation.com

CAPA: Centre for Asian Pacific Aviation. 2010b. European Carriers Now Carry [online], [cited 20 September 2013]. Available from Internet: www.centreforaviation.com

Castillo-Manzano, J. I.; López-Valpuesta, L.; González-Laxe, F. 2011. The effects of the LCC boom on the urban tourism fabric: the viewpoint of tourism managers, Tourism Management 32(5): 1085-1095.

http://dx.doi.org/10.1016/j.tourman.2010.09.008

Cavka, I.; Cokorilo, O. 2012. Cost-benefit assessment of aircraft safety, International Journal of Transportation and Traffic Engineering 2(4): 359-371.

http://dx.doi.org/10.7708/ijtte.2012.2(4).06

Danklefsen, N. 2007. The Consequences of the Growing European Low-cost Airline Sector. Publication IP/B/TRAN/ IC/2006-185. European Parliament, Policy Department Structural and Cohesion Policies.

Debbage, K. G. 1999. Air transportation and urban-economic restructuring: competitive advantage in the US Carolinas, Journal of Air Transport Management 5(4): 211-221. http://dx.doi.org/10.1016/S0969-6997(99)00015-0

Debbage, K. G.; Delk, D. 2001. The geography of air passenger volume and local employment patterns by US metropolitan core area: 1973-1996, Journal of Air Transport Management 7(3): $159-167$. http://dx.doi.org/10.1016/S0969-6997(00)00045-4

Dennis, N. 2007. End of the free lunch? The responses of traditional European airlines to the low-cost carrier threat, Journal of Air Transport Management 13(5): 311-321. http://dx.doi.org/10.1016/j.jairtraman.2007.04.005

Dobruszkes, F. 2006. An analysis of European low-cost airlines and their networks, Journal of Transport Geography 14(4): 249-264. http://dx.doi.org/10.1016/j.jtrangeo.2005.08.005

Doganis, R. 2001. The Airline Business in the 21st Century. New York: Routledge.

Echevarne, R. 2008. The impact of attracting low cost carriers to airports, in Graham, A.; Papatheodouru, A.; Forsyth, P. (Eds.). Aviation and tourism. Hampshire: Ashgate Publishing, 177-191.

European Cockpit Association. 2002. Low-cost Carriers in the European, Aviation Single Market. Brussels: ECA Industrial Sub Group.

Francis, G.; Fidato, A.; Humphreys, I. 2003. Airport-airline interaction: the impact of low-cost carriers on two European airports, Journal of Air Transport Management 9(4): 267273. http://dx.doi.org/10.1016/S0969-6997(03)00004-8

Francis, G.; Humphreys, I.; Ison, S., et al. 2006. Where next for low cost airlines? A spatial and temporal comparative study, Journal of Transport Geography 14(2): 83-94. http://dx.doi.org/10.1016/j.jtrangeo.2005.05.005

Franke, M. 2004. Competition between network carriers and low-cost carriers - retreat battle or breakthrough to a new level of efficiency?, Journal of Air Transport Management 10(1): 15-21.

http://dx.doi.org/10.1016/j.jairtraman.2003.10.008

Gillen, D.; Lall, A. 2004. Competitive advantage of low-cost carriers: some implications for airports, Journal of Air Transport Management 10(1): 41-50. http://dx.doi.org/10.1016/j.jairtraman.2003.10.009

Graham, M. 2009. Different models in different spaces or liberalized optimizations? Competitive strategies among low-cost carriers, Journal of Transport Geography 17(4): 306-316. http://dx.doi.org/10.1016/j.jtrangeo.2009.02.004

Green, R. K. 2007. Airports and economic development, Real Estate Economics 35(1): 91-112. http://dx.doi.org/10.1111/j.1540-6229.2007.00183.x

Hungarian Statistical Office. 2013. Rapid Report on Tourism 2012 [online], Hungarian Statistical Office [cited 20 September 2013]. Available from Internet: http://www.ksh. hu/kereskedelmi_szallashelyek_forgalma 
Janelle, D. G. 2004. Impact of information technologies, in Hanson, S.; Giuliano, G. (Eds.). The Geography of Urban Transportation. $3^{\text {rd }}$ ed. New York: The Guilford Press, 86112.

Jarach, D. 2004. Future scenarios for the European airline industry: a marketing based perspective, Journal of Air Transportation 9(2): 23-39.

Kővári, B.; Török, A. 2010. Social benefit estimation of travel time shortage of air transport in Europe, Transportation Engineering 38(2): 73-77. http://dx.doi.org/10.3311/pp.tr.2010-2.03

Legeza, E. 2001. Connection between airports and their environment [A repülőtér és környezetének kapcsolata], Scientific Review of Transport [Közlekedéstudományi Szemle] 51(7): 263-268 (in Hungarian).

Legeza, E.; Selymes, P.; Torok, A. 2010. Investigation of European air transport traffic by utility-based decision model, Aviation 14(3): 90-94.

http://dx.doi.org/10.3846/aviation.2010.14

Lenartowicz, M.; Mason, K.; Foster, A. 2013. Mergers and acquisitions in the EU low cost carrier market. A Product and Organisation Architecture (POA) approach to identify potential merger partners, Journal of Air Transport Management 33: 3-11.

http://dx.doi.org/10.1016/j.jairtraman.2013.06.005

Levine, M. E. 2009. Airline consolidation: how will it reshape the industry? What does it mean for Europe?, in First annual AirNet lecture. Schiphol.

Mason, K. 2001. Marketing low-cost airline services to business travellers, Journal of Air Transport Management 7(2): 103109. http://dx.doi.org/10.1016/S0969-6997(00)00036-3

Mason, K.; Morrison, W. G.; Stockman, I. 2013. Liberalization of air transport in Europe and the evolution of 'lowcost' airlines, in Forysth, P.; Gillen, D.; Huschelrath, K.; Niemeier, H.-M.; Wolf, T. (Eds.). Liberalization in Aviation: Competition, Cooperation and Public Policy. Ashgate: Aldershot.

Merkert, R.; Morrell, P. S. 2012. Mergers and acquisitions in aviation - management and economic perspectives on the size of airlines, Transportation Research Part E 48(4): 853862. http://dx.doi.org/10.1016/j.tre.2012.02.002

Mirosavljević, P.; Gvozdenović, S.; Čokorilo, O. 2011. A model of air traffic assignment as part of airport air pollution management, Aviation 15(4): 92-100. http://dx.doi.org/10.3846/16487788.2011.651792

Morrison, W. 2004. Dimensions of predatory pricing in air travel markets, Journal of Air Transport Management 10(1): 87-95. http://dx.doi.org/10.1016/j.jairtraman.2003.10.004

Mueller, K.; Hueschelrath, K.; Bilotkach, V. 2012. The construction of a low cost airline network: facing competition and exploring new markets, Managerial and Decision Economics 33(7-8): 485-499. http://dx.doi.org/10.1002/mde.2561

Nolan, J. F.; Ritchie, P.; Rowcroft, J. 2004. September 11 and the world airline financial crisis, Transport Reviews 24(2): 239-255. http://dx.doi.org/10.1080/0144164032000138751

O'Connor, K. 2003. Global air travel: towards concentration or dispersal?, Journal of Transport Geography 11(2): 83-92. http://dx.doi.org/10.1016/S0966-6923(03)00002-4

Pickrell, D. 2004. The regulation and deregulation of US airlines, in Button, K. (Ed.). Airline Deregulation, International Experiences. New York: New York University Press.

Robertson, J. A. W. 1995. Airports and economic regeneration, Journal of Air Transport Management 2(2): 81-88. http://dx.doi.org/10.1016/0969-6997(95)00033-X
Smith, D. S.; Timberlake, M. 1998. Cities and the spatial articulation of the world economy through air travel, in Cicantell, P.; Bunker, S. (Eds.). Space and Transport in the World System. Westport, Ct.: Greenwood Press, 213-240.

Sparaco, P. 2004. Obsolete thinking, Aviation Week and Space Technology 161(7): 37.

Stankūnas, J.; Kondroška, V. 2012. Formation of methodology to model regional airspace with reference to traffic flows, Aviation 16(3): 69-75. http://dx.doi.org/10.3846/16487788.2012.732306

Tretheway, M. 2004. Distortions of airline revenues: why the network airline business model is broken, Journal of Air Transport Management 10(1): 3-14. http://dx.doi.org/10.1016/j.jairtraman.2003.10.010

Tseytlina, T.; Balashov, V.; Smirnov, A. 2013. The problem of modelling a trunk air route network, Aviation 17(1): 1-8. http://dx.doi.org/10.3846/16487788.2013.774939

Vowles, T. M. 2000. The effect of low-fare air carriers on airfares in the US, Journal of Transport Geography 8(2): 121128. http://dx.doi.org/10.1016/S0966-6923(99)00033-2

Warnock, D.; Andrew, S. P. 2005. An exploratory study into airport choice factors for European low-cost airlines, Journal of Air Transport Management 11(6): 388-392. http://dx.doi.org/10.1016/j.jairtraman.2005.05.003

Williams, G. 2001. Will Europe's charters carriers be replaced by "nofrills" scheduled airlines, Journal of Air Transport Management 7(5): 277-286. http://dx.doi.org/10.1016/S0969-6997(01)00022-9 